A.V. Yefimov ${ }^{1}$, DSc, Prof., Yu.V. Romashov ${ }^{1,2}$, DSc, Assoc. Prof.

${ }^{1}$ National Technical University “Kharkiv Politechnical Institute”; 2, Kyrpychova Str., Kharkiv, Ukraine, 61002

${ }^{2}$ V. N. Karazin Kharkiv National University; 4 Svobody Sq., Kharkiv, Ukraine, 61022; e-mail:yu.v.romashov@gmail.com

\title{
THEORETICAL GROUNDS FOR THE EQUIPMENT'S OPERABILITY AND SAFETY ESTIMATIONS OF NUCLEAR POWER PLANTS WITH EMERGENT PROPERTIES TAKING INTO ACCOUNT
}

\begin{abstract}
A.В. Єфімов, Ю.В. Ромашов. Теоретичні основи оцінки працездатності обладнання атомних електростанцій та його безпечної роботи з урахуванням синергетичних ефектів. Обговорюються підходи до оцінки працездатності та безпеки обладнання АЕС. Метою даної статті є концептуальна розробка підходів, моделей і методів, які роблять можливим отримання оцінки працездатності і безпеки AEC з урахуванням можливого виникають властивостей цих систем обладнання. Наукова і практична цінність результатів $є$ розробка підходів, моделей методів, які дозволяють отримати оцінки працездатності експлуатації обладнання та безпеки AEC, беручи до уваги можливі емерджентні властивості, які нехтували в підходах, моделей і методів, добре знаних сьогодні. Розглягуто загальні підходи до побудови математичних моделей відповідального обладнання АЕС, яка 3 урахуванням взаємодії різних зовнішніх факторів, які можуть призвести до синергетичних ефектів. Основний результат $є$ встановлена можливість математичного моделювання обладнання АЕС у вигляді систем, пов'язані крайової і початково-крайових задач, що дозволяє брати до уваги можливі емерджентні властивості. Головний висновок перспективних застосувань методи - дискретизація для чисельного аналізу елементів АЕС. Значення отриманих результатів полягає в розробці теоретичних основ для оцінки працездатності і безпеки АЕС обладнання шляхом з урахуванням можливих емерджентних властивостей.

Ключові слова: елементи обладнання та технологічні процеси АЕС, зовнішні впливові фактори, синергетичні ефекти, працездатність, міцність, руйнування, надійність, математичні моделі, чисельне інтегрування
\end{abstract}

A.V. Yefimov, Yu.V. Romashov. Theoretical grounds for the equipment's operability and safety estimations of nuclear power plants with emergent properties taking into account. The approaches to the evaluation of equipment's operability and safety of NPP are discussed. The purpose of this article is the conceptual development of approaches, models and methods that make possible to obtain assessments of the equipment's operability and safety of NPP taking into account possible emergent properties of the systems. The scientific and practical value of the results of this article is to develop approaches, models and methods that allow us to obtain estimates of the equipment's operability and NPP safety, taking into account the possible emergent properties that are neglected in approaches, models and methods well-known today. General approaches to the construction of mathematical models of the responsible equipment of NPP, which taking into account the interaction of various external factors that can lead to synergistic effects, are considered. The main result is the established possibility of mathematical modelling of NPP equipment in the form of systems of connected boundary and initial boundary value problems, which allows us to take into account possible emergent properties. The main conclusion is promising applications semi-discretization methods for numerical analysis of NPP elements. The value of obtained results consists in developing of theoretical foundations for estimating the equipment's operability and safety of NPP by taking into account possible emergent properties.

Keywords: nuclear power plants, equipment's operability, safety, external influencing factors, emergent properties, mathematical models, numerical integration

Introduction. Estimation of equipment's operability and safety of nuclear power plants, such as in-house devices of nuclear reactors and steam generators, is significantly hampered by the variety of external factors (mechanical and thermal loads, radiations and corrosive aggressive mediums) the results of which exceed the results of these factors individually due to the possible emergent properties. Emergent properties influence on the safety of technical systems has been significantly interested now $[1,2]$. It is important to take into account the emergent properties of the technical system that are not expressed through the properties of the elements entering into it, including in research and ensuring the reliability and efficiency of technology. Prediction of possible emergent properties has the great importance for the safety estimations of nuclear power plants, because it allows us to identify the initial events of the accident and more accurately assess the probability of their occurrence $[3,4]$. 
Evidence of emergent properties presence based on the operation experience of NPP units. At the present time, the problem of the operability estimating of the critical elements of the nuclear power plant equipment, including the in-house elements of nuclear reactors and steam generators, has not been fully resolved, as evidenced by damages of different equipment's elements that occur periodically during the operation of nuclear power units, and the causes of many such damages are still accurate not understanding.

Cases of failure in the operation of the control and protection system due to the delay in the fall of the regulating rods due to the curvature of the guide channels of the fuel assemblies since 1992 have been recorded on most VVER-1000 units [5]. The causes of the guide channels curvature consist in the loss of stability due to excessive compression [5], which agrees with the approximate estimates of the critical compressive forces of the guide channels [6]. Although the measures taken to reduce the compressive forces have led to a positive effect [5], the reasons for the excessive "clamping" of the guide channels have not been precisely established and, apparently, are due to the emergent properties of the complex of external factors.

There are all known cases of depressurization of fuel rod cladding [5], which can be dangerous because of the increase in radioactivity of the coolant because the cladding is the first protective barrier separating nuclear fuel from the surrounding environment; exceeding the permissible number of destroyed fuel cladding requires the shutdown of the nuclear reactor and the reloading of nuclear fuel. Depressurization is a consequence of the destruction of the material of the fuel cladding, which occurs with the simultaneous occurrence of many processes, including thermo elastic deformation, corrosion damage, creep, embrittlement under mechanical contact between fuel and cladding, or high gas overpressure, which are determined by thermal conductivity and heat transfer, emission of gaseous products fission and diffusion [7]. Thus, the destruction of the fuel cladding should be considered as the emergent properties effect, i.e. as an unobvious result of the interaction of a multitude of factors. At the same time, there is an uncertainty of the initial data necessary for estimating the durability of the fuel cladding [8], which leads to the possibility of destruction due to the unevenness of the neutron flux and the probabilistic nature of nuclear reactions and other factors.

The damages of the output collectors were discovered in 1986 after several years of operation on 25 PGV-1000 steam generators and led to repairing of two and replacing the 23 steam generators at operating NPP [9]; these damages are due to the emergent properties presence and, as noted in [9], are caused by the complex multifactor effect of different nature factors. It was possible to develop measures that reduce the residual stresses and allow excluding such damage of the output collectors in the future [9], despite the lack of a deep understanding of the processes that caused damage. Nevertheless, the study of the damaging process of the output collectors of PGV-1000 steam generators is of considerable interest, especially due to the fact that the damages was observed only at the output collectors having a lower temperature than the input collectors.

Damages of the heat exchanging pipes of steam generators of NPPs with VVER are due to the corrosion cracking of stainless steels [9]. The stress corrosion cracking occurs only under the combined action of tensile stresses and corrosive environments [10] and must be considered as the emergent properties effect. It is required the development of a model for stress corrosion cracking of stainless steels [10], taking into account the mechanical stress factors and chemical composition of the corrosive medium, to estimate the quantitative data about the effect of mechanical stress factors and chemical properties of the corrosive medium on cracking time and reliability parameters of heat exchanging pipes of steam generators of nuclear power plants with VVER which was carried out in [11]. The results of the researches $[10,11]$ showed that relatively small changes in the tensile stress and concentration of the corrosive component lead to a significant change in the time of stress-corrosion cracking of the heat exchanging pipes of steam generators of NPP with VVER, which explains the possibility of cracking of individual heat exchanging pipes and the normal operation of other heat exchanging pipes in one steam generator at the same time. More reasonable estimates of cracking time require researches of regularities in the concentration of corrosive active components on heat exchanging piped of steam generators of nuclear power plants. 
The damage to equipment elements observed during the operation of NPP units before the completion of the design life indicates some drawbacks of the approaches traditionally used to assess the operability, for example [12]. These drawbacks are associated from the point of view of the system approach [13] with the use of the decomposition method - dividing the system under consideration into subsystems, as, for example, in [12], where they consider separately instant destruction due to high mechanical loads exceeding the yield strength and long-term failure due to creep, fatigue, embrittlement and other factors. Naturally, the decomposition does not allow for the consideration of emergent properties, and it is therefore not surprising that the damage to the equipment observed during the operation of NPP units before the end of the design life is due to synergistic effects that cannot be predicted by traditional approaches. Although relatively infrequent failures of NPP equipment due to emergent properties in most cases do not create significant difficulties for further operation, the development of approaches to a more reliable assessment of equipment performance and safety through the consideration of emergent properties is significantly interested from the point of view of developing prospective NPP projects.

Models of the state of NPP equipment elements for operability estimating taking into account the emergent properties. The calculated estimation of the operability of the critical elements of the NPP equipment is based on the study of the regularities of these elements deformation by various external influencing factors generated in different modes of operation, which eventually leads to the achievement of the limiting state, which is realized, for example, in strength calculation standards [12]. Evaluation of the influence of some emergent properties on the operability of NPP equipment elements is possible if we take into account the influence of several external factors affecting the regularities of the deformation of the equipment elements, such as, for example, in [14], where the influence of stress-corrosion cracking and creep on the deformation and failure of pipes was taken into account. A general approach to constructing mathematical models of the deformation of NPP equipment elements, taking into account the influence of several external factors, can be proposed on the basis of the results of $[10,11,14-16]$, and let consider this approach further.

Let denote as $\mathbf{u}^{(1)}$ the vector with components, which define the stress-strain and temperature state of the equipment's element of NPP; the vector $\mathbf{u}^{(1)}$ can be consisted on the stress and strain tensor's and displacement vector's components, temperature and heat flow vector's components. The NPP structural element can be deformed by the external mechanical loads under the influence of creep, corrosion-active compounds and other factors, which can be leaded to the material properties changing and other changings in structural element's state. Let denote as $\mathbf{u}^{(2)}$ the vector with components, which define the processes influencing on the stress-strain and temperature state of equipment's element of NPP; the vector $\mathbf{u}^{(2)}$ can be consisted the creep deformation tensor's components, concentrations of diffusing corrosive components, etc. Disregarding the forces of inertia, as is customary, for example, in calculating the strength of NPP equipment [12], we present the model of deformation of the NPP structural element in the form of a boundary value problem:

$$
\mathbf{A}^{(1)}\left(\mathbf{u}^{(1)}, \mathbf{u}^{(2)}\right)=\mathbf{f}^{(1)}\left(\mathbf{u}^{(2)} ; \mathbf{z}\right) \forall \mathbf{x} \in Y, \quad \mathbf{L}^{(1)}\left(\mathbf{u}^{(1)}, \mathbf{u}^{(2)}\right)=\mathbf{p}^{(1)}\left(\mathbf{u}^{(2)} ; \mathbf{z}\right) \forall \mathbf{x} \in \mathbf{U},
$$

where $\mathbf{A}^{(1)}$ and $\mathbf{f}^{(1)}$ are the operator and the vector, corresponding to the differential equations, $\mathbf{L}^{(1)}$ and $\mathbf{p}^{(1)}$ are the operator and the vector, corresponding to the boundary conditions of the mathematical model of the NPP structural element deformation; $\mathbf{z}$ is the vector with components, which define the external influencing factors; $\mathbf{x}, Y$ and $v$ are the vector of the point's coordinates, domain and the boundary surface of the body representing the NPP structural element.

The equations and boundary conditions of a deformable solid body mechanics, in which the influence of processes characterized by a vector $\mathbf{u}^{(2)}$ was considered, are usually the equations and boundary conditions in problem (1). The simplest example is the equations of the theory of elasticity, in which the constants characterizing the properties of materials (modulus of elasticity, etc.) depend on the concentration of hydrogen diffusing into the structural material. 
Boundary value problem (1) defines the stress-strain and temperature states of the NPP structural element for the given vector $\mathbf{u}^{(2)}$. To consider the influence of the processes characterized by the vector $\mathbf{u}^{(2)}$ on the NPP structural element deforming it is necessary to solve the boundary value problem (1) with the equations, which define the vector $\mathbf{u}^{(2)}$ changing during the operating time $t$; these equations lead us to the initial boundary value problem, which can be represent in generalized form as:

$$
\begin{array}{ccc}
\frac{\partial \mathbf{u}^{(2)}}{\partial t}+\mathbf{A}^{(2)}\left(\mathbf{u}^{(2)}, \mathbf{u}^{(1)}\right)=\mathbf{f}^{(2)}\left(\mathbf{u}^{(2)}, \mathbf{u}^{(1)} ; \mathbf{z}\right),\left.\quad \mathbf{u}^{(2)}\right|_{=0}=\mathbf{u}_{0}^{(2)} & \forall \mathbf{x} \in Y, \\
\mathbf{L}^{(2)}\left(\mathbf{u}^{(2)}, \mathbf{u}^{(1)}\right)=\mathbf{p}^{(2)}\left(\mathbf{u}^{(2)}, \mathbf{u}^{(1)} ; \mathbf{z}\right) & \forall \mathbf{x} \in \mathrm{U}, &
\end{array}
$$

where $\mathbf{A}^{(2)}$ and $\mathbf{f}^{(2)}$ are the operator and vector, corresponding to the differential equations, $\mathbf{L}^{(2)}$ and $\mathbf{p}^{(2)}$ are the operator and vector, corresponding to the boundary conditions of the mathematical model of the processes influencing on the NPP structural element; $\mathbf{u}_{0}^{(2)}$ if the field of the vector $\mathbf{u}^{(2)}$ in the beginning moment $t=0$ of the time.

The initial boundary value problem (2) makes it possible to describe, for example, the process of hydrogen corrosion, which is the diffusion of hydrogen into the structural material and, as a result, leading to a change in the properties of this material, as considered, for example, in [17]. The description of the creep strains can also be represented in the simplest partial form (2) corresponding to the initial problem for the creep strain field, as discussed, for example, in [16]. We can introduce a vector $\mathbf{u}^{(3)}$ and the equations, boundary and initial conditions necessary for its determination to take into account other factors affecting the deformation of NPP equipment elements and not represented in the vector $\mathbf{u}^{(2)}$, etc. An example is the continuous corrosion consideration, when the vector $\mathbf{u}^{(3)}$ contains parameters characterizing the degree of corrosion damages of the structural element, the depth of the layer destroyed by corrosion under the boundary surface of the metal for example. We take into account that solid corrosion changes the geometry of the considered element of equipment; we assume that the rate of continuous corrosion can depend only on the stress-strain state, and as a result we obtain a model of continuous corrosion in a generalized form [18]

$$
Y=Y\left(\mathbf{u}^{(3)}\right), \quad v=v\left(\mathbf{u}^{(3)}\right) ; \quad \frac{\partial \mathbf{u}^{(3)}}{\partial t}=\mathbf{f}^{(3)}\left(\mathbf{u}^{(3)}, \mathbf{u}^{(1)} ; \mathbf{z}\right),\left.\quad \mathbf{u}^{(3)}\right|_{t=0}=\mathbf{u}_{0}^{(3)},
$$

where $\mathbf{f}^{(3)}$ is the vector function, which define the continuous corrosion velocity corresponding to the assumed mathematical model; $\mathbf{u}_{0}^{(3)}$ is the vector, defining the initial field of the vector $\mathbf{u}^{(3)}$.

The continuous corrosion's accounting leads us to difficult mathematical problem of the solving of the boundary value problem (1) and the boundary value problem (2) with a movable boundary, which is defined by the relations (3). In some cases the numerical integration of the equations of the stress-deformed state with the movable due to continuous corrosion boundary was discussed in [18] for example.

Mathematical models presented in the form (1) - (3) for describing deformation and their application for the operability estimations of NPP equipment elements constitute the central idea of the work [15], in which some synergetic effects due to interference of various external factors, in particular the effect of creep on stress corrosion cracking [14].

The vector $\mathbf{z}$ contained in (1) - (3), which can characterize, for example, pressure, temperature, concentration of corrosive-active components and other characteristics of working mediums, as well as force fields and radiation acting on equipment elements, was considered in [15] as predetermined; vector's $\mathbf{z}$ components values was chose for the considered as the expected operating conditions. The approach to modeling the deformation of NPP equipment elements, based on the construction of boundary, initial and initial-boundary value problems (1) - (3) developed in [15], can be substantially expanded due to a more valid definition of the external factors presented by the vector $\mathbf{z}$. In fact, the 
vector $\mathbf{z}$ can be considered not predetermined a priori, but to determine it as the result of programs of control actions corresponding to different modes of operation of NPP units, taking into account the influence on the stress-strain vector $\mathbf{u}^{(1)}$ and damage vector $\mathbf{u}^{(2)}$ of the equipment's structural elements. This can be realized if we will propose a mathematical model for determining the vector $\mathbf{z}$ :

$$
\frac{\partial \mathbf{z}}{\partial t}+\mathbf{A}^{(z)}\left(\mathbf{z}, \mathbf{u}^{(1)}\right)=\mathbf{f}^{(z)}\left(\mathbf{z}, \mathbf{u}^{(1)} ; \mathbf{c}\right),\left.\mathbf{z}\right|_{l=0}=\mathbf{z}_{0} \quad \forall \mathbf{x} \in Y^{(z)} ; \mathbf{L}^{(z)}\left(\mathbf{z}, \mathbf{u}^{(1)}\right)=\mathbf{p}^{(z)}\left(\mathbf{z}, \mathbf{u}^{(1)} ; \mathbf{c}\right) \quad \forall \mathbf{x} \in \mathrm{v}^{(z)},
$$

where $\mathbf{A}^{(z)}$ and $\mathbf{f}^{(z)}$ are the operator and vector, corresponding to the differential equations, $\mathbf{L}^{(z)}$ and $\mathbf{p}^{(z)}$ are the operator and vector, corresponding to the boundary conditions of the mathematical model of the external influencing factors leads to the deformations and damages of the NPP structural elements during the operation; $\mathbf{c}$ is a vector of the technological process control parameters; $\mathbf{z}_{0}$ is the field of the vector $\mathbf{z}$ in initial time moment $t=0 ; Y^{(z)}$ and $v^{(z)}$ are the domain and the boundary surface of the volume in which occur the technological processes that generate the external influencing factors of the structural elements.

Relations (4) represent the mathematical model of the technological process of an NPP unit's equipment (a nuclear reactor or steam generator for example) or some subsystem of its (a fuel assembly or a fuel rod for example), depending on the operability of which element is researched. An example of the dependence of the vector's $\mathbf{z}$ velocity of a on the vector $\mathbf{u}^{(1)}$ is the dependence of the pressure in the fuel rod (the vector's $\mathbf{Z}$ component) on the gap between the fuel and the cladding, which also depends on the radial displacement of the inner surface of the cladding (the vector's $\mathbf{u}^{(1)}$ component) [7]. The vector $\mathbf{c}$ corresponds to the process control program and, of course, must be predetermined; different modes of operation of NPP equipment correspond to their vectors $\mathbf{c}$, so that solving the related problems (1)-(4), we can estimate the deformation of NPP equipment's elements taking into account emergent properties in different operating modes.

Numerical integration of differential equations of mathematical models of the state of NPP equipment elements taking into account emergent properties. It is necessary to use numerical methods for the related systems of differential equations with the boundary and initial conditions (1)(4) solving to the operability estimating of NPP structural elements, because analytical solutions can't be obtained because due to the nonlinear terms present in the differential equations and boundary conditions. In [15], [16] it was suggested to apply the Bubnov-Galerkin method for numerical integration of systems of equations involving problems (1) - (3) and was shown that many problems can be effectively solved by this approach. The technique of the Bubnov-Galerkin method applying for solving problem (1) - (3) consists in the fact that this problem is represented in the form of a single operator equation:

$$
\frac{\partial \mathbf{u}}{\partial t}+\mathbf{A}(\mathbf{u})=\mathbf{f}(\mathbf{u} ; \mathbf{z}),\left.\quad \mathbf{B}(\mathbf{u})\right|_{=0}=\mathbf{u}_{0}^{(2)} \quad \forall \mathbf{x} \in Y ; \mathbf{L}(\mathbf{u})=\mathbf{p}(\mathbf{u} ; \mathbf{z}) \quad \forall \mathbf{x} \in \mathrm{v},
$$

where $\mathbf{u}$ is the vector including all the components of the vectors $\mathbf{u}^{(1)}$ and $\mathbf{u}^{(2)}$; operators and vector functions included in the differential equations, boundary and initial conditions have a block structure and contain corresponding operators from (1) and (2).

To satisfy boundary conditions from (1), (2) the methods of R-functions developed by academician V.L. Rvachev and his followers were used in [15], [16], but the structure of solutions that exactly satisfy all the boundary conditions are represented in the generalized matrix form:

$$
\mathbf{u}_{n}=\mathbf{u}_{\mathrm{v}}+\mathbf{U}_{n} \cdot \mathbf{a}_{n}(t),
$$

where $\mathbf{u}_{n}$ is the approximation of the desired solution that exactly satisfies the boundary conditions and corresponds to the number $n$ of trial functions; $\mathbf{u}_{v}$ is the vector function and $\mathbf{U}_{n}$ is the matrix 
composed of trial functions whose components are constructed with the help of R-functions; $\mathbf{a}_{n}(t)$ is the vector containing the coefficients to be determined.

To determine the vector $\mathbf{a}_{n}(t)$, in accordance with the Bubnov-Galerkin method, we use the condition that the residual of the differential equations is equal to zero, which leads to a system of ordinary differential equations:

$$
\left(\int_{Y}\left(\mathbf{U}_{n}\right)^{T} \cdot \mathbf{U}_{n} d Y\right) \frac{d \mathbf{a}_{n}}{d t}+\int_{Y}\left(\mathbf{U}_{n}\right)^{T} \cdot \mathbf{A}\left(\mathbf{u}_{v}+\mathbf{U}_{n} \cdot \mathbf{a}_{n}\right) d Y=\int_{Y}\left(\mathbf{U}_{n}\right)^{T} \cdot \mathbf{f}\left(\mathbf{u}_{\mathrm{v}}+\mathbf{U}_{n} \cdot \mathbf{a}_{n}(t) ; \mathbf{z}\right) d Y .
$$

The initial conditions are satisfied by the method of least squares:

$$
\frac{d}{d \mathbf{a}_{n}(0)} \int_{Y}\left(\mathbf{B}\left(\mathbf{u}_{v}+\mathbf{U}_{n} \cdot \mathbf{a}_{n}(0)\right)-\mathbf{u}_{0}^{(2)}\right)^{2} d Y=0 .
$$

Thus, the problem (1), (2) was reduced to the integration of the ordinary differential equations (7) with allowance for the initial conditions presented in the form (8). The experience of solving creep problems [16] shows that for the integration of differential equations (7), the Merson method [19, 20] is very effective, in which the integration step is automatically selected in accordance with the given permissible error of integration. In this case, the error of the resulting approximate solution should theoretically decrease with increasing the number $n$ of trial functions, and, as a consequence, an approximate solution obtaining with an acceptable accuracy requires the calculating a large number of integrals representing the coefficients of the differential equations (7), which can be very laborious even for modern computers.

The error of the approximate solutions of problem (1), (2) essentially depends on the error in calculating the coefficients of the differential equations (7) by approximate integration, for example, quadrature formulas using. As a consequence, approximate solutions obtaining with an allowable error requires large amounts of computation, which was noted in [16] in the context of creep problems. Because of this, we have to find more efficient methods than those proposed in [15], [16] for numerical integration of coupled systems of differential equations with boundary and initial conditions (1) - (4). An analysis of the experience of Japanese specialists in modeling the behavior of fuel elements of nuclear reactors [7] testifies to the effective application of finite difference methods and finite elements for the solution of such problems requiring analysis of thermal conductivity, diffusion, deformation taking into account creep and contact interaction.

A key problem in using the finite-difference method for solving the initial-boundary value problem (5) is to determine the relationship between the time $\boldsymbol{t}$ integration step and the spatial coordinates $\mathbf{x}$, which is complicated by the fact that the operators of the initial-boundary value problem (5) have a block structure corresponding to equations (1) - (4) of different types. In [7], the step of integration over time changes in the process of solving the problem, when modeling the behavior of fuel elements using finite-difference and finite elements methods. Thus, the effectiveness of the Merson method for the theory of creep problem solving [16] is apparently connected with the possibility of automatically choosing the time integration step.

As an alternative to the approach proposed in [15], [16] on the basis of the Bubnov-Galerkin method for solving problems like (1) - (4), we can consider a semi-discretization method [21], in which finite-difference formulas are applied only for spatial coordinates $\mathbf{x}$ and the result is a system of ordinary differential equations with respect to time-dependent nodal values. The solution of differential equations obtained in this way should be performed numerically by the Merson method and, by automatically selecting the integration step, coordinate the integration step with respect to time and spatial coordinates. As applied to the initial-boundary value problem (5), this approach leads to ordinary differential equations: 


$$
\frac{\partial \mathbf{u}_{n}}{\partial t}+\mathbf{A}_{n}\left(\mathbf{u}_{n}\right)=\mathbf{f}_{n}\left(\mathbf{u}_{n} ; \mathbf{z}\right)
$$

where $\mathbf{u}_{n}$ is the vector of nodal values of unknowns; $n$ is the number of grid nodes; $\mathbf{A}_{n}\left(\mathbf{u}_{n}\right)$ is the operator and $\mathbf{f}_{n}\left(\mathbf{u}_{n} ; \mathbf{z}\right)$ is the vector function, obtained as a result of the transition from continuous functions to their nodal values by means of finite-difference formulas for the derivatives with respect to the spatial coordinates $\mathbf{x}$.

The application of the differential-difference method (9) makes it possible, without significant difficulties, to satisfy the initial conditions and boundary conditions, as in the method of finite differences. In this case, the matrices of the coefficients of the differential equations (9) will be band-like, in contrast to the densely filled matrices of the coefficients of the differential equations (7), which, when using special computational methods, will make it possible to dispense with smaller volumes of required computational memory. As applied to the solution of the problems of creep theory, considered earlier in [18] with the help of the Bubnov-Galerkin method, recent studies have shown considerable advantages of the semi-discretization method. The publication of the results of these studies is of particular interest.

Conclusions. The presented research results allow us to conclude:

- the consideration of possible emergent properties is the current trend in the problem of operability estimation of NPP equipment's structural elements critical for the operational efficiency and the nuclear safety;

- mathematical models allowing to take into account possible emergent properties, can be presented in the form of related boundary and initial boundary value problems, each of which describes the particular processes occurring during the operation of NPP equipment;

- necessary for the operability estimation mathematical models of deformation and fracture of NPP equipment's structural elements can be considered together with mathematical models of appropriate technological processes that take into account the control program, which requires interdisciplinary studies of mechanics of deformable solids, reactor physics, heat conductivity and heat transfer and other areas;

- it is of considerable interest to develop numerical methods for solving systems of coupled boundary and initial boundary value problems that combine differential equations of different types. In this connection, a differential-difference method is promising, in which the resulting ordinary differential equations are solved using the Merson method with an automatic choice of the integration step.

\section{Література}

1. Johnson, Christopher W. What are emergent properties and how do they affect the engineering of complex systems? / Johnson, Christopher W. // Reliability Engineering \& System Safety. - 2006. - № 91(12). - P. 1475-1481. DOI:10.1016/j.ress.2006.01.008

2. Flage, R. Emerging risk - Conceptual definition and a relation to black swan type of events / R. Flage, T. Aven. // Reliability Engineering \& System Safety. - 2015. - № 144. - P. 61 - 67. DOI:10.1016/ j.ress.2015.07.008

3. Дыбач, А.М. Синергия в областях деятельности по обеспечению ядерной безопасности и ядерной защищенности АЭС / А.М. Дыбач, И.Я. Кузмяк, А.В. Кухоцкий // Ядерна та радіаційна безпека. - 2013. - № 4(60). - С. 38 - 41.

4. Дыбач, А.М. Методологические основы анализа и учета неопределённостей вероятностного анализа безопасности АЭС / А.М. Дыбач // Ядерна та радіаційна безпека. - 2014. - № 4(64). - С. 8 - 16.

5. Активные зоны ВВЭР для атомных электростанций / В.Д .Шмелев, Ю.Г. Драгунов, В.П. Денисов, И.Н. Васильченко. - М.: ИКЦ «Академкнига», 2004. - 220 с.

6. Ефимов, А. В. Потеря устойчивости и форма возможного изгиба направляющих каналов тепловыделяющих сборок ядерных реакторов ВВЭР-1000 / А.В. Ефимов, М.В. Максимов, Ю.В. Ромашов // Ядерна та радіаційна безпека. - 2015. - № 4(68). - С. 14 - 18. 
7. Suzuki, M. Light water reactor fuel analysis code FEMAXI-V (Ver.1). JAERI-Data/Code 2000-030 / M Suzuki. - Tokai: Japan Atomic Energy Research Institute, 2000. - 285 p.

8. Влияние неопределенности исходных данных на оценку долговечности оболочки твэла при переменном режиме эксплуатации / М.В. Максимов С.Н. Пелых, О.В. Маслов, В.Е. Баскаков // Ядерна та радіаційна безпека. - 2009. - № 2. - С. 13 - 19.

9. Парогенераторы реакторных установок ВВЭР для атомных электростанций / Б.И. Лукасевич, Н.Б. Трунов, Ю.Г. Драгунов, С.Е. Давиденко. - М.: ИКЦ «Академкнига», 2004. - 391 с.

10. Morachkovskii, O.K. Continual model of propagation of corrosion cracks for the evaluation of the service life of structures / O.K. Morachkovskii, Yu.V. Romashov // Materials Science. - 2010. - Vol. 46, № 2. - P. $254-259$.

11. Ромашов, Ю.В. Оценка показателей долговечности теплообменных труб парогенераторов АЭС с ВВЭР на основе континуальной модели коррозионного растрескивания / Ю.В. Ромашов // Ядерна та радіаційна безпека. - 2012. - № 3(55). - С. 16 - 20.

12. Нормы расчета на прочность элементов оборудования и трубопроводов атомных энергетических установок (ПНАЭ Г-7-002-86). - М.: Энергоатомиздат, 1989. - 525 с.

13. Дж. ван Гиг. Прикладная общая теория систем: в 2-х кн. / Гиг Дж. ван - М.: Мир, 1981. - 733 с.

14. Morachkovskii, O.K. Prediction of the corrosion cracking of structures under the conditions of hightemperature creep / O.K. Morachkovskii, Yu.V. Romashov // Materials Science. - 2011 - Vol. 46, № 5. P. $613-618$.

15. Ромашов, Ю.В. Метод определения ресурса эксплуатации и показателей долговечности элементов конструкций тепловых и ядерных энергоустановок / Ю.В. Ромашов // Вісник Національного технічного університету «Харківський політехнічний інститут». - Харків: НТУ «ХПІ». - 2013. № 14(988). - C. 62 - 71 .

16. Morachkovskii, O.K. Solving initial-boundary-value creep problems / O.K. Morachkovskii, Yu.V. Romashov // International Applied Mechanics. - 2009. - Vol. 45, № 10. - P. 1061 - 1070.

17. Андрейків, О.С. Механіка руйнування та довговічність металевих матеріалів у водневмісних середовищах / О.С. Андрейків, О.В. Гембара; Фізико-механічний ін-т ім. Г.В. Карпенка НАН України. - К.: Наук. думка, 2008. - 344 с.

18. Ромашов, Ю. Узагальнене формулювання та наближене розв'язання задач про лінійно-пружне деформування тіл з рухомими границями для дослідження впливу суцільної корозії / Ю. Ромашов // Теорія та практика раціонального проектування, виготовлення і експлуатації машинобудівних конструкцій: Тези доповідей. - Львів: КІНПАТРІ ЛТД, 2012. - С. 50 - 51.

19. Butcher, J.C. A history of Runge-Kutta methods / J.C. Butcher //Applied numerical mathematics. 1996. - Vol. 20. - P. 247 - 260.

20. Hoffman, J.D. Numerical Methods for Engineers and Scientists / J.D. Hoffman, S. Frankel. - New York Basel: Marcel Dekker, Inc., 2001. - 825 p.

21. Fletcher, C.A.J. Computational techniques for fluid dynamics 1 Fundamental and General Techniques / C.A.J. Fletcher. - Berlin-Heidelberg: Springer-Verlag, 1988, 1991. - 404 p.

\section{References}

1. Johnson, Christopher W. (2006). What are emergent properties and how do they affect the engineering of complex systems? Reliability Engineering \& System Safety, Volume 91, Issue 12, 1475-1481. doi:10.1016/j.ress.2006.01.008

2. Flage, R. and Aven T. (2015). Emerging risk - Conceptual definition and a relation to black swan type of events. Reliability Engineering \& System Safety, Volume 144, 61-67. doi:10.1016/j.ress.2015.07.008

3. Dybach, O., Kuzmiak, I., \& Kukhotsky, O. (2013). Sinergiya v oblastyakh deyatel'nosti po obespecheniyu yadernoy bezopasnosti i yadernoy zashchishchennosti AES [Synergy in the Areas of NPP Nuclear Safety and Nuclear Security]. Yaderna ta radíatsíyna bezpeka - Nuclear and Radiation Safety, 4(60), 38-41.

4. Dybach, O. (2014). Metodologicheskiye osnovy analiza i ucheta neopredelonnostey veroyatnostnogo analiza bezopasnosti AES [Methodological Basis for Analysis and Accounting of NPP Probabilistic Safety Analysis Uncertainties]. Yaderna ta radíatsíyna bezpeka - Nuclear and Radiation Safety, 4(64), 8-16.

5. Shmelev, V. D., Dragunov, Yu. G., Denisov, V.P., \& Vasilchenko, I. N. (2004). Aktivnyye zony VVER dlya atomnykh elektrostantsiy [Active zones VVER for atomic power stations]. Moscow: IKTs “Akademkniga”. 
6. Yefimov, A., Maksymov, M., \& Romashov, Yu. (2015). Poterya ustoychivosti i forma vozmozhnogo izgiba napravlyayushchikh kanalov teplovydelyayushchikh sborok yadernykh reaktorov VVER-1000 [Loss of Stability and Possible Bending Shape of WWER-1000 Fuel Assemblies Guide Tubes]. Yaderna ta radíatsíyna bezpeka - Nuclear and Radiation Safety, 4(68), 14-18.

7. Suzuki, M. (2000). Light water reactor fuel analysis code FEMAXI-V (VER. 1). Tokai: Japan Atomic Energy Research Institute.

8. Maksimov, M., Pelykh, S., Maslov, O., \& Baskakov, V. (2009). Vliyaniye neopredelennosti iskhodnykh dannykh na otsenku dolgovechnosti obolochki tvela pri peremennom rezhime ekspluatatsii [Influence of initial data uncertainty upon estimation of the fuel element cladding durability at a variable operation mode]. Yaderna ta radíatsíyna bezpeka - Nuclear and Radiation Safety, 2, 13-19.

9. Lukasevich, B. I., Trunov, N. B., Dragynov, Yu. G., \& Davydenko, S. E. (2004). Parogeneratory reaktornykh ustanovok VVER dlya atomnykh elektrostantsiy [Steam generators of VVER reactors for nuclear power plants]. Moscow: IKTs “Akademkniga”.

10. Morachkovskii, O. K. and Romashov, Yu. V. (2010). Continual model of propagation of corrosion cracks for the evaluation of the service life of structures. Materials Science, Vol. 46, No. 2, 254-259. doi:10.1007/s11003-010-9281-5.

11. Romashov, Y. V. Otsenka pokazateley dolgovechnosti teploobmennykh trub parogeneratorov AES s VVER na osnove kontinual'noy modeli korrozionnogo rastreskivaniya [Assessment of Reliability Indices for WWER Steam Generator Heat Exchange Tubes Based on a Continuum Stress-Corrosion Cracking Model]. Yaderna ta radíatsíyna bezpeka - Nuclear and Radiation Safety, 3(55), 16-20.

12. Normy rascheta na prochnost' elementov oborudovaniya i truboprovodov atomnykh energeticheskikh ustanovok (PNAE G-7-002-86) [Norms for calculating the strength of equipment elements and pipelines of nuclear power plants (PNAE G-7-002-86)]. (1989). Moscow: Energoatomizdat.

13. Van Gigch, John. (1978). Prikladnaya obshchaya teoriya sistem : v 2-kh [Applied general systems theory]. Moscow: Mir.

14. Morachkovskii, O. K. and Romashov, Yu. V. (2011). Prediction of the corrosion cracking of structures under the conditions of high-temperature creep. Materials Science, Vol. 46, No. 5, 613-618. DOI: 10.1007/s11003-011-9331-7.

15. Romashov, Yu. V. (2013). Metod opredeleniya resursa ekspluatatsii i pokazateley dolgovechnosti elementov konstruktsiy teplovykh i yadernykh energoustanovok [Method for determining service life and durability indices of structural elements of thermal and nuclear power plants]. Bulletin of NTU “KhPI”. Series: Power and heat engineering processes and equipment, no 14(988), 62-71.

16. Morachkovskii, O. K., \& Romashov, Yu. V. (2009). Solving initial-boundary-value creep problems. International Applied Mechanics, Vol. 45, No. 10, 1061-1070.

17. Andreikiv, O. E., \& Hembara, A. V. (2008). Mekhanika ruynuvannya ta dovhovichnist' metalevykh materialiv u vodnevmisnykh seredovyshchakh [Fracture mechanics and durability of metal materials in Hydrogen-containing mediums] Kiev: Naukova dumka.

18. Romashov, Yu. (2012). Uzahal'nene formulyuvannya ta nablyzhene rozv'yazannya zadach pro liniynopruzhne deformuvannya til z rukhomymy hranytsyamy dlya doslidzhennya vplyvu sutsil'noyi koroziyi [Generalized formulation wand approximate solution of linear-elastic deformable bodies with floating boundaries for continuous corrosion effect analysis]. Theory and practice of rational design, construction and operation of engineering constructions: Abstracts. Lviv: “2KINPATRI LTD”.

19. Butcher, J. C. (1996). A history of Runge-Kutta methods. Applied numerical mathematics, Vol. 20, 247-260.

20. Hoffman, J. D. \& Frankel, S. (2001). Numerical Methods for Engineers and Scientists, Marcel Dekker Inc., New York-Basel.

21. Fletcher, C. A. J. (1988, 1991). Computational techniques for fluid dynamics 1 Fundamental and General Techniques. Springer Verlag. Berlin: Heidelberg. 